\title{
The Memoirs of Marguerite de Valois
}

Experience of Knowledge, Knowledge of Experience

Les Mémoires de Marguerite de Valois, expérience des savoirs, savoirs de

l'expérience

\section{Caroline Trotot}

Translator. Colin Keaveney

\section{(2) OpenEdition}

\section{Journals}

Electronic version

URL: http://journals.openedition.org/aes/728

DOI: $10.4000 /$ aes. 728

ISSN: 2258-093X

\section{Publisher}

Laboratoire LISAA

\section{Electronic reference}

Caroline Trotot, "The Memoirs of Marguerite de Valois », Arts et Savoirs [Online], 6 | 2016, Online since 07 July 2016, connection on 21 April 2019. URL : http://journals.openedition.org/aes/728; DOI :

10.4000/aes.728

This text was automatically generated on 21 April 2019.

Centre de recherche LISAA (Littératures SAvoirs et Arts) 


\title{
The Memoirs of Marguerite de Valois
}

\author{
Experience of Knowledge, Knowledge of Experience \\ Les Mémoires de Marguerite de Valois, expérience des savoirs, savoirs de \\ l'expérience
}

\section{Caroline Trotot}

Translation : Colin Keaveney

1 Written in response to Brantome's portrait of the queen which was seen as overly flattering, Marguerite de Valois' Memoirs claim to be a diffracted self-portrait in which a true-to-life image is constructed through the process of writing. Throughout the text, the author offers Brantôme pieces of information meant to allow him to correct a picture that has become false over time. Marguerite works to reconstruct past episodes that correspond to different facets of her identity. Her writing assembles the knowledge necessary to rectify the errors commited by her friend - the first being his failure to account for time, which she refers to as Fortune (in contrast to Nature) ${ }^{1}$ (p. 46). The Memoirs are thus an exercise in self-knowledge that reflects an anthropological outlook. This temporal vision of the human being draws on Marguerite's philosophical knowledge, as well as on her conception of history and of politics. As a good humanist, one who had had conversations with Montaigne and to whom "L'apologie de Raimond Sebond" ${ }^{2}$ was apparently dedicated, she put the considerable learning she had to the test of lived experience ${ }^{3}$, and of writing, wheighing her knowledge against an encounter with learning and the world that takes on meaning in the liveliness of her individual account. It is the interaction among these different types of knowledge - and their relationship to her writing that we shall now examine.

\section{The Memoirs and the Philosophy of History}

2 The opening of the Memoirs presents the work as a response to Brantôme's Discourse on Marguerite, a text judged by the queen to be too laudatory ${ }^{4}$. Marguerite reproaches its author with creating an idealised portrait that did not take into account the effects of 
time. Now, the beautiful portrait drawn by Brantôme, a political manifesto against Salic law, was imbued with a Neo-Platonic philosophy that exalted the correspondence between the lovely appearance of the princess and her moral and intellectual virtues ${ }^{5}$. In reality, Marguerite's Memoirs distance themselves from this whole system of representation.

3 First of all, she chooses to introduce herself via a narrative designed to better illustrate the influence of Fortune on the nature of her being. The form she adopts shows the importance she gives to time, thereby guaranteeing a continuity to the work better than a rhetorically structured argument could. She thus intimates that being is not the product of an unchanging essence, but rather the result of a way of living. Her positioning of the Saint Bartholomew's Day Massacre under the sign of good fortune turned bad (p. 67) echoes the Aristotelian philosophy of Louis Le Roy, who explained in De la vicissitude ou variété des choses en l'univers $(1575)^{6}$ that the world is structured by oppositions and that this struggle gives form to time. Marguerite is careful to combine historical and biographical narration, a feature that would become characteristic of the genre of autobiography more generally. When writing about herself, she chooses episodes that are never purely personal: they are always linked to the lives of the elite and to the royal family, which shows how impossibly difficult it is to separate public and private selves and furthermore implies that each affects the other. She is not merely recording a situation deriving from a particular social condition; even less is she painting a background. Instead, - events and political decisions are shown to be integral to the way individuals are formed. It is thus important to give appropriate emphasis to the connection she makes between the first anecdote she cites from her childhood and the accidental death of Henri II, 'which deprived France of peace, and our family of happiness' (p. 48). The unexpected passing of Henri II weakened royal power and played an important role in the Wars of Religion, a history in which Marguerite was both victim and actor. Marguerite gives an account of a life in history, which is not a hall of mirrors with ideals on one side and their incarnations on the other - but instead a world of political careers and pragmatic choices, a history that is Fortune in action, but also constituted by human action. This is a history that is both endured and made.

4 The individual is affected by episodes that form a chain (or chains) of cause and effect in which the subject reveals her virtues. As always in the Renaissance, history is a "magistra vitae" offering ethical teachings. Critics have successfully established that Marguerite thus sought to make public her attachment to her faith to the crown. It is also demonstrably the case that she offers an analysis of the behaviour of the nobility in terms that are distinctively philosophical in tone. Thus, regarding the reserve shown by Catherine de Médicis in reaction to Henri d'Anjou's speech after the battle of Jarnac, Marguerite remarks that she merely highlighted important passages in his speech: "[... ] moderating her actions at will, seemingly showing that the discrete person does only what she wishes to do, with no thought to manifestations of joy and public statements of praise [...]."

5 The discrete person is the 'prudent person', according to Henri Estienne's 1549 FrenchLatin dictionary, the one who shows himself capable of this Aristotelian virtue (i.e. phronesis), a virtue placed under the sign of moderation (since in medio stat virtus). This is the essential virtue prized by history according to Amyot: "the reading of history teaches

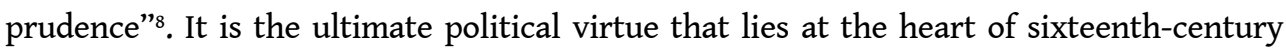
thought and, in particular that of Montaigne, as Francis Goyet showed in Les Audaces de la 
Prudence 9 . In harmony with this philosophical framework, "prudence operates [...] in tandem with Fortune ${ }^{10}$ and enables the individual to navigate through history. The recurrence of these terms in connection with political figures in the Memoirs inspires a reflection on the possible political meaning of this work. Situating herself in the tradition of Plutarch's Parallel Lives and the political memoirs of Commines and Martin Du Bellay ${ }^{11}$, albeit obliquely (given her status as a woman in exile and her chosen style of writing), Marguerite questions the behaviour and decisions of all and sundry. She fashions a "political mirror" of her own character as a woman politician, at once the object of decisions, notably the one that saw her married off to Henri de Navarre, and an actor, as when she supported Alençon or participated in the Flemish negotiations recounted in the Memoirs, or even in her writing, which could be considered a form of historical action. Her deployment of art (and its dissimulation) can also be understood as a practical application of prudence as suggested by Francis Goyet in the case of Montaigne ${ }^{12}$.

6 Prudence is the virtue of the individual acting in time. It includes, in part, caution. The prudent person takes the vicissitudes of history into account when making decisions. She keeps in mind past actions when preparing for the future. She thus uses a practical form of knowledge, an art, as by Aristotle in his Politics and Nicomachean Ethics, texts well known to Marguerite who attended the royal academy (Académie du palais) as indicated by the 1576 register of speeches annotated in her hand ${ }^{13}$. The speech attributed to Catherine de Médicis and written in order to appease Henri III's anger after Henri de Navarre's escape is a perfect example of this prudent taking of time into account:

[She said] that all things in this world had two faces, and that once this one, which was sad and terrible, had turned away and we got to then see the other side, things would seem more agreeable and tranquil; we could take new counsel from new events; that there might come a time when he would have need of my services; and that, as prudence counselled us not to place too much confidence in our friends, lest they should one day become our enemies, so was it advisable to conduct ourselves in such a manner with our enemies as if we had hopes they might hereafter become our friends. ${ }^{14}$

7 Marguerite seems to have absorbed this political prudence at the end of the Memoirs when Henri de Navarre asks her to brave Biron "with all his rough and disdainful talk" (p. 194):

I dealt with this impassioned order with the help of my brother's advice and the discretion necessary in such matters, in full knowledge that one day he would regret his actions since such a nobleman might be of much assistance in the future. ${ }^{15}$ (p. 195)

8 Prudence comes from experience. And Marguerite proceeds in her Memoirs from ignorance born of inexperience to knowledge born of experience. It is this experience that engenders a knowledge of reality unimpeded by false appearances or by emotion ${ }^{16}$. Marguerite describes her childhood self thus:

Too young and inexperienced as I was, I did not question this good fortune! And considering permanent the happy state I enjoyed, with not a thought that it might change, I took it for granted! (p. 59) ${ }^{17}$

On the other hand, she begins the last paragraph of the Memoirs with the following remark: "All these shows of apparent benevolence did not fool me with regard to what one should expect from the court, for I had long experience of the realities. (p. 213)"18

10 The Memoirs tell how Marguerite became prudent, how she learned to apply at virtue that requires her to take time into account. Thus, when at Cambrai in Flanders, she comments on Monsieur d'Inchy's conduct as follows: 
[...] he left him to come talk to me during the ball, and to bring me afterward to the collation of sweets - imprudently, it seems to me, given that he was in charge of the citadelle. I am speaking about it in too knowledgeable a way as a result of having learned more about how to go about defending a fort than I ever would have wished. ${ }^{19}$ (p. 125)

11 Here Marguerite plays on the duality of her role, on what she knows as a narrator and as a character. This prolepsis anticipates the years spent in Agen et Usson. Marguerite thus shows the role of experience in learning and in the process of writing through which successive moments are linked together. She emphasizes the political significance of the trip through Flanders, when she observed close-up the major players in one of the principal European conflicts of the period, which had a direct bearing on the Wars of Religion in France and occasioned a very important change in political thought ${ }^{20}$. The Memoirs tell how Marguerite became prudent, how she learned to apply the virtue that she had observed - a virtue that required an ability both to act and to reflect on these actions, that obliged her to consider the role the role played by time, and that articulated internal life to external behavior.

Marguerite responded to Brantôme's immutable portrait, which turned her into the incarnation of beauty, knowledge, intelligence and virtue, by expressing her intellectual and moral virtues through a dynamic form of writing and calling on numerous areas of learning in order to place them at the service of a new type of knowledge of herself and her contemporaries. In the process, she questioned the possibility of faithfully representing individuals through writing and, going further, called into doubt the NeoPlatonic model positing a correspondence between interior and exterior, a model upon which the Valois monarchy relied.

\section{A World of Representations: Negotiating Appearances in the Valois Court}

The problem of representation occurs as a fundamental motif in of these memoirs which place the question of self-representation in the context of the codes of political and social representation. The Valois understood their exercise of power within a Neo-Platonic framework in which politics was an imitation of cosmic harmony. To rule was at once a public relations exercise and a dream, one which the events from the 1560 s until the end of the century proved to be cruelly ill-founded. The reality of human action was grounded in pragmatic approach that derived, at best, from Aristotle and, at worst, from Machiavelli himself, or even from a French reception of Machiavelli that had twisted his thought into a polemical weapon for use against Catherine and her children. In the Memoirs, Marguerite offers the self-portrait of someone shaped by experience and by a learning process that led her to uncouple appearances from reality. In the process, she paradoxically discovered within herself the dualities that writing allowed her to express.

13 At the very beginning of the work, Marguerite brings up a facetious anecdote in order to underscore the complicated relationship between individual and text. She explains that she does not recognise herself in what Brantôme has written:

[...] like old Madame de Randan who, having foregone looking in mirrors after the death of her husband, upon coming on her face perchance in someone else's mirror, asked who that person over there was. ${ }^{21}$ 
The Memoirs assert that there is a divide between inside and outside in order to explore the complexities of the relationship between essence and existence. They interrogate the correspondence between being and appearance and question the unity of being over time. Representation furnishes multiple images diffracted by time, like those that $\mathrm{Du}$ Bellay offers of Rome in his Antiquités, and whose antanaclasis "chercher Rome en Rome" ("seeking Rome in Rome") Marguerite paraphrases. The Neo-Platonic notion of representation, according to which a beautiful appearance corresponds to an unchanging nature, does not convey the truth of being. And, if we enjoy contemplating the "destruction of Troy" (p. 46) in literature, as she suggests, Marguerite is perhaps also inviting the reader to consider the destruction of the world of her childhood, at a time when the French imagined they were Trojans. The Memoirs paint a portrait of their author engaged in a kind of apprenticeship, which allows her little by little to recognise the prudence of the political players around her, but which also permits her to partially adopt this virtue, if not politically, at least insofar as it enriches into her literary style. The claim to truth, which governs the book, conflicts with the complex relationship between interiority and exteriority. The Memoirs are not content to record facts and observable data; they map out the internal space in which decisions are made and feelings are born, and they seek in various ways to describe the relationship between these two spheres. They seek to represent the truth of an inner feeling, one that is subjective and even foreign to the outside world, and to investigate the way our internal self encounters others and perceives them, as well as the way in which our language can "represent" to them what is inside us or alternatively can protect it through dissimulation. This experience is fundamental to the pragmatics of politics, but it is also more universal, and in this sense shapes identity. Here, it might be added that the years that form the backdrop to Marguerite's tale are those in which we see the emergence of a notion of religious conscience in texts that encouraged the latter's safeguarding and refused attempts at spiritual coercion. Furthermore, Protestantism questioned the link between religion and forms of observance. In her discussion of Jeanne d'Albret's death (p. 66), Marguerite makes reference to the 'small apparel' permitted by the Huguenots, so different from the 'the pomp and ceremony of our religion'.

The Memoirs can thus also be read as an interrogation of the political, anthropological and literary role of representation. Beginning with the depiction of childhood, each section deals with one or another aspect of this question. The anecdote about the choice between the duc de Guise and the marquis de Beaupréau (p. 48-49) suggests that Marguerite places no trust in the beauty of a blond-haired child whom history will show to be violent. The next episode (p. 49-51), devoted to the vitally important Colloquium of Poissy, demonstrates that Marguerite's Catholic conscience was already present in childhood and was capable of resisting outside pressures; conversely, the court seemed infested by "wretched Huguenot influences" ("l'impression de la malheureuse huguenoterie" [p. 49]), which led Henri d'Anjou into dissimulation, lies and calomny ${ }^{22}$. The episode that follows (p. 51-53) has often appeared of secondary importance, for it describes a very fine party given by the Valois, that Marguerite attended as a child and that does not seem to have much significance for her life. On the other hand, it has a very definite historical significance $^{23}$. During the Royal Tour of France of 1564-1566, there was a meeting between the envoys of Philip II of Spain, his wife Elisabeth de Valois (daughter of Catherine) and the Duc d'Albe. Catherine was attempting to pacify the kingdom by consolidating Charles IX's royal status and to neutralise a possible intervention by Philip II. Marguerite says 
that her recollections of this period have "vanished from her memory like a dream". She then calls on Brantôme, saying to him "I want to make sure that you will depict the superb banquet given by my mother on the island [...]" and, in a page-long parenthesis, she herself describes the scene, in which it seemed as if "Nature had designed it [the layout of the room] for this purpose". The description concludes with her recalling a storm that put an end to the party. Marguerite depicts it in this way:

[...] the beautiful ballet whose glory was so galling to envious Fortune that she called down such a strange rain and storm, so that the confusion of the retreat that had to be undertaken at night and by boat provided as much to laugh at in the stories told the following day as the magnificent banquet arrangements had provided satisfaction..$^{24}$

16 The text creates a mise en abyme around the question of representation: it describes the effect of the discourse commenting on the abrupt conclusion of the performance. It thus reaffirms the power of the celebration organized by the Valois, all the while underlining the vanity involved. According to historians, the range of details recalled by Marguerite reflects her understanding of the political stakes involved in these spectacles ${ }^{25}$. The subtle opposition between nature and Fortune links this episode to those that precede it, as well as to the incipit. The text thus takes its place as part of a narrative in which each section involves the problem of representation.

The next episode (p. 53-59) is devoted to the relationship between Henri and Catherine in 1569. In three movements, Marguerite shows the prudence displayed by Catherine and Henri in their use of words, the feelings of each member of the family and the instrumental function that the family as a whole is forced to fulfill. Marguerite plays on the different registers of representation in order to show how these registers dictate behavior and how she herself learns little by little to recognise them and no longer simply to endure their effects. Describing Catherine's great delight as she listened to Henri d'Anjou making a fine speech in the wake of his victory at Jarnac, Marguerite thus writes: "What my mother, who loved him most particularly, felt at this cannot be put into words, no more than could the depth of the mourning of Iphigenia's father."26

Marguerite is pointing simultaneously to the prudent dissimulation of the queen, the difficulty involved in conveying the tensions between inside and outside, the suffering the young girl went through as a result and, finally, the ironic distance she tries to maintain when dealing with Henri and Catherine. With Catherine, Marguerite played the role of a 'second self', as Henri had requested she do when he was away, but the way she writes already calls this situation, which denies her individuality, into question. The series of episodes leading up to the wedding and the Saint Bartholomew massacre heighten these effects. The case of Henri d'Anjou definitely makes the point. Catherine's "idol" gave a speech written by someone else whose ethos was not really in keeping with his own. He was obsessed with Le Guast who, as Marguerite puts it, possessed him so that he "could no longer see except through his eyes, nor speak except through his mouth" (p. 59). The gods had abandoned the Princes, thereby making way for demons, and a NeoPlatonism based on Aristotelian virtue had been replaced by "tyrannical maxims" and "fine Machiavellian precepts" (p. 60).

Marguerite thus offers a model, the product of learning tempered by experience, for deciphering the court. She follows in the footsteps of Commynes, who drew pragmatic and moral lessons from his observation of history. The interpretative model she proposes is similar to certain modern analyses of the French court as a sphere of representation 
and of the political use of representation as an instrument of domination, notably those of Norbert Elias ${ }^{27}$ and Louis Marin ${ }^{28}$. It also accords with polemical analyses undertaken by Marguerite's contemporaries and particularly the readings of Machiavelli by opponents of the king ${ }^{29}$, the best example of which is the Discours sur les moyens de bien gouverner et maintenir en bonne paix un royaume ou autre principauté, [...] Contre Nicolas Machiavel Florentin, by Innocent Gentillet, which appeared in 1576 and was dedicated to François d'Alençon. The author writes "against the authors of tyranny exercised in France for the past fifteen years or more" ${ }^{\prime 30}$ and offers a refutation of the maxims derived from Machiavelli's text. Along with its chronological organisation, which has Marguerite's story running parallel to the political history of France, Marguerite's narrative explores representation, offers a hermeneutics of individual behavior and of history. Her text combines a series of perspectives that the reader is encouraged to use in order to interpret both Marguerite's past and the history of France. Each episode turns the court into a sphere of display where the great and the good are no longer divine incarnations referred to by the rhetorical device of antonomasia and featured in court parties $^{31}$, but rather actors in a tragi-comedy. "The Court is a Proteus that changes shape from one hour to the next, and where novelty is constant" (p. 145). Marguerite's narrative breaks up the system of representation by removing the virtuous underpinnings underlying appearances. The court hence becomes a world of dissimulation born either of prudence or of "malice".

With regard to her own past, Marguerite seems to be telling the tale of the difficulties of assuming an identity. Torn between two models of masculinity as a young child, she was rejected by her brother who considered her at best a reflection of his own worth and an instrument to be used. She accepted the rules of her milieu in which appearances, socially speaking, were everything, as is clear from the depiction of her surprise at Henri's request that she leaves childhood behind in order to take up her place close to Catherine: "since I had until then lived a carefree existence, with thought only for dancing and hunting, having until then had no interest in dressing up or appearing beautiful" (p. 57). Another striking example of this phenomenon lies in the account of the embassy of the king of Portugal: "My mother instructed me to get dressed up in order to receive them, which I did" (p. 63). The difficulty of constructing her identity in a situation where her status as an object was in conflict with her status as an intelligent, educated and loyal subject, and where it was impossible for her to "show her innocence" (p. 61), manifested itself in sickness, explained as a symptom of the violence inflicted by calumny and separation from the queen mother (p. 62-63). The sick body conveys in its "sighs" a truth that cannot be expressed in words. It makes manifest a repressed subjectivity, far removed from the facade constructed for the purposes of court life. The events of SaintBartholomew's Day mark the transformation of Marguerite from an object magnificently attired for her wedding and displayed before the onlooking crowds, to a subject during her interview with her mother a few days later. The Queen of Navarre could then speak and assume the choice of this marriage that had been imposed upon her. The framing of the narrative and the arrangement of its motifs offer an anthropological and political perspective that shows how difficult it is for the individuals to construct themselves in a world where taking on an identity amounts to disappearing. Over the course of these episodes, the Memoirs tell of a growing gap between inward being and the world and the emergence of a subjectivity suspicious of appearances. In this process, reading, which "awakens our soul within ourselves", plays a major role (p. 112). Reading allows us to discover the Good and to recognise God within ourselves. Marguerite explains of how her 
captivity in the Louvre converted her to reading, which permitted her to detach herself from a universe of deception in order to learn about the world in books and to recognise the innermost self, the home of knowledge and devotion.

21 Her return to the world outside brought with it an introduction to the use of words as tools for prudently expressing her identity. One episode in particular seems to represent this phenomenon through another mise en abyme. Marguerite depicts herself with Catherine, who is questioning her about the escape of her brother:

So, finding myself torn between two dire possibilities, either to betray the loyalty I owed my brother, thus putting his life at risk, or to swear to an untruth, something I wouldn't have wished to do even to save my life a thousand times over, I felt such confusion that, if God had not helped me, my behavior would have given away what I feared would be discovered without me even saying a word. [...] I showed such composure in language and facial expression that she only managed to learn what I wished her to know and I caused no offense to either my soul or my conscience by swearing false oaths ${ }^{32}$. (p. 175)

The literary text represents the moment when perplexed ambivalence turns into the deployment of ambiguity. Here Marguerite outlines the private space inhabited by the thinking person - an identity anchored in connections and values that lend meaning to individual existence (so much so that in the end Marguerite swears on it with her life). She experiences the powers of language and its capacity to shape the individual in her relationship to others. The literary text bears witness to the duality - between a social self and an underlying personal identity appearing beneath the mask (a recurrent motif in the Memoirs) - that brings the individual into being. The episode of the forced reconciliation between Henri III's and d'Alençon's favourites, which precedes the one above, testifies to the force of this double relation. Here, Marguerite underscores the disjunction between appearances and inner feelings:

[my mother] ordered my brother and me to change our clothes [...] She was obeyed when it came to things that could be taken off or put back on; but, when it came to the face, which is the moving picture of the soul, the justified discontent we were feeling was as obvious as if it had been stamped there with the power and violence of the righteous rancour and disdain we were feeling under the influence of the events of this tragic-comedy. ${ }^{33}$ (p. 172-173)

The metaphor of the theatre shows the role played by literary models in the deciphering of reality. At this court that enjoys theatre shows with such relish, literature mirrors life; it is the fabric on which life imprints a pattern that reveals its meaning. This dialectical relationship is illustrated in the depiction of a surprising character:

[...] the chevalier de Seurre (whom the queen, my mother, had handed over to my brother so that he could sleep in his room, and whom she liked sometimes to hear talk because of his frankness, and who freely said whatever he wanted, having something of the cynical philosopher about him) [...] [declared]: "It is too little if the idea is to be open, and too little if the idea is to mislead". And, turning to me so that she could not hear him, he said: "I suspect this is not the last act in this game; I'd be amazed if our man (meaning of my brother) let things lie" ${ }^{34}$ (p. 173)

The court is the place where literary models are acted out and literature the space in which individual experience is represented and considered. The cynical philosopher is a model of philosophical and linguistic irony, of the way literature as a mode of thinking and verbal expression shapes the individual. He uses cynical "tropes" ${ }^{35}$, paradoxical maxims that call into question social appearances in order to discover human truths. Marguerite thus uses the resources of writing in order to create a flexible space in which 
the individual avoids being constrained, puts her subjectivity to use and shapes her authorial identity. She exposes the individual to the world of knowledge and reshapes this world according to her experience, an experience consisting of prudent confrontation, of inadequate analogies and of ironic distancing.

\section{Literary Strategies for the Construction of the Individual Subject of Experience}

The initial presentation of the Memoirs as an oral response introduces the basic fiction of a personal contribution to a broader discussion that took place in both speech and writing. Marguerite shows that the individual is constituted through her dialogue with others. But this same introduction reveals the complexity of this largely polyphonic form of speech. Like all Renaissance texts, the Memoirs present themselves as a "second-hand" ${ }^{36}$ form of writing; they are woven out of quotations with multiple and often ambiguous functions.

From the outset, quotations are used in loose, allusive, virtually metaphorical fashion. Marguerite is Rome (p. 46). Her childhood becomes the starting point of the Memoirs, as is the life of Theseus in Parallel Lives, translated by Amyot. This inappropriate reworking of a reference calls attention to the choices made by the author and calls into question her position vis a vis the reader. Marguerite points out the difficulty of distinguishing myth from history in autobiography as well as in biography:

[...] [actions] as worthy of being described as those of the childhood of Themistocles and Alexander, the former having put himself at risk in the middle of the road before the advancing horses of a charioteer who had refused to heed his call to stop, the latter disdaining the honours of winning a race if he had not done so against kings. ${ }^{37}$ (p. 48)

Her text thus places itself in a complex way under the patronage of Amyot's Plutarch. This learned reference allows her to lay claim to the double authority of both Amyot and Plutarch and invites comparisons between the great men of the Lives and the protagonist of the autobiography. But the parallel is rejected as soon as it is made. Marguerite thus opens up an indeterminate space, comparable to the terrae incognitae she first mentions, in which the reader is to create the picture of her life. The process of constructing an identity becomes even more complex in the following paragraph, with the anecdote in which Henri II asks the child to choose between two boys. We are thus encouraged to compare this anecdote with the ones already mentioned. They seem to have nothing to do with one another even as they strikingly reveal the immobility that characterises the princess' childhood. Perhaps they also show her prudence. On the other hand, one might wonder if the anecdote dealing with Alexander should not at least be read allegorically since hunting was one of her regular pursuits (p. 57) and "riding out with kings" could have a wider significance for Marguerite's life.

The narrative voice becomes ironic here in its use of comparisons that make the reader uncertain as to the position of the author. In the space that opens up between authorised knowledge and the subject-object that she offers for consideration, Marguerite claims her authorial freedom. Similarly, when Henri asks her to be his representative to Catherine during his absence, she facetiously refers to a famous biblical passage: "[...] I was this close to answering him, like Moses did to God in the burning bush: Who am I? Send the one you must send" 38 (p. 57) 
29 It is difficult to see Marguerite as Moses, Henri as Yahweh and Catherine as Pharaoh. The reference to this famous passage of the Old Testament moreover evokes the solemnity of a Protestant rhetoric that interprets history as a form of foreshadowing. We are thus encouraged to read the quotation ironically, as a mise en abyme of the way Marguerite finds her own voice through her dialogue with the authority figures of her brother and mother. Indeed, she adds:

[...] finding within myself what I never thought was there (powers stirred up by the content of his words, powers unknown to me even though [I had been] born with quite a bit of courage), once I had gotten over this initial surprise, these words appealed to me; and it suddenly seemed to me that I had been transformed, and that I had become something more than I had been until then. I began to grow in confidence, and I said to him: "My brother [...]"39

The deployment of parenthesis to bracket particular elements combined with the use of concession, opens up secondary perspectives that complicate the apparent simplicity of the transformation. The multi-layered discourse structures the polyphony that allows Marguerite to detach the narrative voice from that of the character who promises her brother that "my being with the queen, my mother, is like you being there yourself" and to distance herself from the character to whom Catherine says "it will be a great pleasure for me to speak to you as if to your brother. Give yourself over to me, and do not fear to speak to me freely, for I wish it so"40. (p. 58). Marguerite thus shapes her story as one in which a speaking subject learns to dissociate what is said from the person speaking, and to discern difference notwithstanding her desire to be on equal footing with her brothers. A reader of Montaigne, she appears to be retracing the meanderings of his chapter entitled "On Experience". Experience is the form of knowledge that allows us to understand what is singular. "Dissimilitude effortlessy infiltrates our works [...] Likeness does not unite as powerfully as difference pulls asunder." ${ }^{41}$ Approximations, diversions and false pairings allow us to perceive in the mirror the individual who cannot quite recognise herself, or only partially recognises herself. And it is by observing others in comparative perspective that we get to know what it is to be human. Montaigne once again seems to offer insight on the Memoirs:

By dint of having trained myself from childhood to scrutinise my life through observing others, I became quite expert in this area; and, when I put my mind to it, I give little away about myself in this respect, whether in terms of expressions, my mood, or what I say. ${ }^{42}$

31 Henri thus represents a negative self that Marguerite challenges a posterior ${ }^{43}$. He is also Catherine's favourite, as Marguerite, in all probability, would have liked to have been. Marguerite creates history based upon the image she wishes to project of herself, and she chooses Henri as the main target for her irony. She writes history retrospectively, drawing on the experience gained over long years, but she is not too far from historical reality if Thierry Wanegfellen ${ }^{44}$, for example, is to be believed. He thinks that Henri, who was close to the Guise family, had perhaps "conceived the Saint Bartholomew massacre as a sort of coup d'état allowing him to become the principal figure in the royal state, riding on the immense popularity he enjoyed in anti-Protestant circles [...]" and that this involvement of a member of the royal family in the massacre probably made any crackdown on the Guise family impossible.

Moving well beyond self-justification, the techniques used in the Memoirs depict the changing face of the Valois court, from the fabrication of a glorious historical narrative to the fracture of the Wars of Religion. The canny use of asides allows Marguerite to 
distinguish her voice from those of the rest of the royal family, thus showing the stakes involved during the rise of absolutism. Hence, beginning with Henri's speech after Jarnac, she revealingly uses mocking parenthetical remarks:

[...] he delivered an oration containing a complete explanation of the way he was carrying out his charge [...] with so much skill and eloquence, and such grace that he earned the respect of everyone present - even more so given that his great youth enhanced and made even more apparent the prudence of his words (more suited to a great beard and an old captain than to a young adolescent of sixteen, whose brow was already garlanded with the laurels of two battle victories) and that beauty, which makes all acts pleasing, was so vigorous in him that it seemed to seek to rival his good fortune in order to see which of them would bring him more glory. ${ }^{45}$ (p. 54-55)

It was the old maréchal Tavannes that had written the speech. While the glory of the victory is real, that of the speech is hollow. And what about the glory of beauty? Marguerite then adds an anecdote about the veil of Timanthes that is obviously sinister in tone. It is no longer a matter of depicting the sublimity of the political sacrifice, but rather of stressingthe culpable blindness of a happily prudent mother. The slipperiness of the discursive system here allows the author to avoid being pinned down.

Marguerite also deploys metaphors as ironic quotations in order to create axiological resemblances. Thus, she has Henri say à propos of Charles that he fears that he "does not always get much pleasure out of hunting, but with his newfound ambition he would like to replace the hunting of animals with the hunting of men" (p. 56). Here she sketches Henri's cruelty while also recalling that Charles had been referred to in a Protestant pamphlet, the Réveille-matin des français, as an "unloyal hunter" 46 . She may even be referencing by implication the murky dealings of Henri against Charles IX. Later, she would write of the "pumpkin" Le Guast (p. 92), a metaphor once used by Ronsard to describe denizens of the court, Ronsard himself having been attacked by Protestants as the ultimate Catholic courtier for the Valois. As we can see, Marguerite chooses her metaphors, quotations and discursive strategies from the books with which she is familiar. She thus distinguishes herself quite clearly from other authors of memoirs writing not long before her, such as Jean de Mergey, who also recounts the SaintBartholomew massacres, or her mother-in-law Jeanne d'Albret, who tells of her political engagement in the 1560s, inasmuch as these predecessors frequently use popular tropes or anecdotes in which any sense of a personal voice is $\operatorname{lost}^{47}$. These juicy example establish complicity with a sort of universalized meta-reader, one who participates in the same discursive community and shares the same type of wisdom. Marguerite, for her part, quotes phrases that evoke particular authors, but we do not always know what she is getting at or her attitude with regard to what is being expressed. She uses Tacitus and Gentillet, but it is not possible to say for sure whether she is on the side of Alençon or the Protestants. Certain phrases seem repeated from one passage to the next as cases of autonymical antanaclases that alert the reader to the meaning of important terms. Catherine loves Henri 'uniquely', Madame de Sauve leads each of her lovers to believe that she loves them "uniquely"(p. 91) and, finally, Madame de Tournon loves her daughter "uniquely" too, despite driving her to death because of her pitiless heardheartedness (p. 141). Henri employs "tyrannical maxims", the political players in Flanders discuss Spanish tyranny (p. 130-131) and Alençon that of his brother's (p. 165): finally the reader is invited to include in this series the metaphorical tyranny of mademoiselle de Tournon (p. 141). 

of a victim, but her argument is quite different from that of Jeanne d'Albret, for example. The ambiguous tone, woven out of humanist learning employed in complex fashion, makes for a moving and meaningful text, one which invents "Memoirs" as a genre and which provides an exceptional insight into the life of the court. It can be read in many ways -the mark of a great work of literature. However, this epistemological flexibility, which would be cited favourably in the case of other writers - in the cases of Commynes' Memoirs and Josephus' Jewish Wars even treason is seen as constitutive discursive act - is considered in Marguerite's case as a degrading form of feminine weakness. Yet the ambiguities inherent in her identity ${ }^{49}$ exemplify the paradoxes of the modern self. Her text can be understood as the fashioning of an authorial identity, that brilliantly reveals the power systems in which she was enmeshed, thanks to her contradictory status as royal princess and then childless queen. Hers is a magisterial contribution to Renaissance self-fashioning ${ }^{50}$ and she helped to construct the spiral staircase from the top of which Norbert Elias imagined Renaissance Man contemplating himself ${ }^{{ }^{1}}$. She fulfills the program laid out by Montaigne in the final chapter of his Essays, which reminds us both that "know thyself" was engraved on the pediment of the temple of Apollo, god of knowledge, and that "Plato also says that prudence is nothing more than the enactment of this prescription" ${ }^{\prime 2}$.

\section{NOTES}

1. References to the Memoirs will be placed between brackets throughout the article and will refer to the following edition: Marguerite de Valois, Mémoires et Discours, éd. Éliane Viennot, SaintEtienne, Publications de l'Université de Saint-Étienne, 2004. See also the useful edition: Marguerite de Valois, Mémoires et autres écrits, Éliane Viennot ed, Paris, Champion, 1999, french text online http://www.elianeviennot.fr/Marguerite/MgV-Memoires.html, accessed 15 May 2016.

2. É. Viennot, Marguerite de Valois, Paris, Payot, 1993, p. 187 et 236; J. Coppin, "Marguerite de Valois et le Livre des créatures de Raymond Sebond", Revue du seizième siècle, tome X, 1923, p. 57-66.

3. É. Viennot, "Parler de soi: parler à l'autre. Marguerite de Valois face à ses interlocuteurs", Tangence, $\mathrm{n}^{\circ} 77,2005$, p. 37-59, p. 52: “De fait, c'est tout l'être qui a changé, et qui s'est avant tout 
chargé d'expérience: de la politique, de la guerre, de l'amour, de la vie"; to which can be added "de l'écriture" ("On Writing'), begun in the correspondence, and doubtless lost works of poetry. The last chapter of Montaigne's Essais (III, XIII) is entitled "De l'expérience" ("On Experience").

4. G. Shrenck, "Brantôme et Marguerite de Valois: d'un genre l'autre ou les Mémoires incertains", La Cour au miroir des mémorialistes, 1530-1682, Actes du colloque de Strasbourg, 1989, N. Hepp ed., Paris, Klincksieck, 1991, p. 183-192 ; É. Viennot, “Les métamorphoses de Marguerite de Valois, ou les cadeaux de Brantôme", in Jean-Philippe Beaulieu and Diane Desrosiers-Bonin eds., Dans les miroirs de l'écriture. La réflexivité chez les femmes écrivains de l'Ancien Régime, Montréal, Paragraphes, 1998, p. 83-94.

5. After ten pages describing Marguerite's physical appearance, Brantôme writes: “C'est assez, si me semble, d'avoir parlé de la beauté de son corps, encores que le subject en soit si ample qu'il meriteroit une decade : toutesfois j'espere d'en parler encores ailleurs; mais il faut dire quelque chose de sa belle ame, qui est si bien logée en si beau corps." [It is enough, it seems to me, to have spoken of the beauty of her body, even though the subject fully deserves a week; however, I hope to speak of it again elsewhere; but something must be said about her beautiful soul, which is so aptly accommodated in such a beautiful body.] Brantôme, Recueil des Dames, Étienne Vaucheret ed., Paris, Gallimard, “bibliothèque de la Pléiade”, 1991, p. 130.

6. Louis Le Roy, De la vicissitude ou variété des choses en l'univers, Paris, Fayard, 1988, p. 17.

7. “[...] modérant ses actions comme elle voulait, montrant apparemment que le discret ne fait rien qu'il ne veuille faire, sans s'amuser à publier sa joie et à pousser ses louanges dehors [...]." (p. 55)

8. La "lecture des Histoires est une école de prudence", Les vies des hommes illustres, grecs et romains, comparées l'une avec l'autre par Plutarque de Chaeronee, Translatées de grec en françois par M. Jaques Amyot conseiller du Roy, et grand ausmonier... Lausanne, Jean Le Preux, 1578, préface au lecteur.

9. Francis Goyet, Les Audaces de la prudence, Paris, Garnier, 2009.

10. Ibid., p. 44.

11. According to the inventory made after her death, Marguerite owned these works. See MarieNoëlle Baudoin-Matuszek, «La bibliothèque de Marguerite de Valois », Henri III Mécène, Paris, PUPS, 2006, p. 274-292.

12. Francis Goyet, op. cit., p. 92-95.

13. François Rouget, “Les orateurs de 'La Pléiade' à l'Académie du Palais (1576): étude d'un album manuscrit ayant appartenu à Marguerite de Valois”, Renaissance and Reformation/Renaissance et Réforme, 31.4, automne, 2008, p. 19-42.

14. "[elle dit] que toutes les choses du monde avaient deux faces, que cette première, qui était triste et affreuse étant tournée, quand nous viendrions à voir la seconde, plus agréable et plus tranquille, à nouveaux événements, on prendrait nouveau conseil ; que lors peut-être on aurait besoin de moi ; que comme la prudence conseillait de vivre avec ses amis comme devant un jour être ses ennemis, pour ne leur confier rien de trop, qu'aussi l'amitié venant à se rompre et pouvant nuire, elle ordonnait d'user de ses ennemis comme pouvant être un jour amis." (p. 104)

15. "J'usai de ce commandement passionné avec le conseil de mon frère et la discrétion requise en telles choses, sachant bien qu'un jour il en aurait regret, pouvant espérer beaucoup d'assistance d'un tel cavalier." (p. 195)

16. "Tut! Envy and hate hold the eyes in thrall so that they never see things as they really are". ("Mais quoi! l'envie et la haine fascinent les yeux, et font qu'ils ne voient jamais les choses telles qu'elles sont." p. 195)

17. “Trop jeune que j'étais et sans expérience, je n'avais à suspecte cette prospérité! Et pensant le bien duquel je jouissais permanent, sans me douter d'aucun changement, j'en faisais un état assuré!" (p. 59)

18. "Toutes ces belles apparences de bienveillance ne me faisaient point tromper aux fruits que l'on doit espérer de la Cour, en ayant eu par le passé trop d'expériences." (p. 203) 
19. “[...] il le laissa pour m'entretenir durant le bal, et pour après me mener à la collation de confitures - imprudemment ce me semble, vu qu'il avait charge de la citadelle. J'en parle trop savante à mes dépens, pour avoir plus appris que je n'en désirais comme il se faut comporter en la garde d'une place forte." (p. 125)

20. Blandine Kriegel, La République et le Prince moderne, Paris, P. U.F., 2011, particularly p. 83.

21. “[...] comme la vieille Madame de Randan, qui ayant demeuré depuis la mort de son mari sans voir miroir, rencontrant par fortune son visage dans le miroir d'une autre, demanda qui était celle-là." (p. 47).

22. We cannot here go into all the different terms analysed in these pages.

23. Jean Boutier, Alain Dewerpe, Daniel Nordman, Un tour de France royal, le voyage de Charles IX (1564-1566), Paris, Aubier, 1984.

24. “[...] ce beau ballet, duquel la Fortune envieuse ne pouvant supporter la gloire fit orager une si étrange pluie et tempête, que la confusion de la retraite qu'il fallait faire la nuit par bateaux apporta le lendemain autant de bons contes pour rire, que ce magnifique appareil de festin avait apporté de contentement) [...]" (p. 53).

25. Ibid., p. 56, on the subject of regional dances used by Catherine's for political ends, as mentioned by Marguerite and not by Jouan, the royal chronicler.

26. “Ce qu'en ressentait ma mère, qui l'aimait uniquement, ne se peut représenter par paroles, non plus que le deuil du père d'Iphigénie." (p. 54)

27. Norbert Elias, La société de cour, trans. P. Kannitzer and J. Etoré, Paris, Flammarion, "Champs", 1985.

28. Louis Marin, Le Portrait du roi, Paris, Minuit, 1981.

29. Quentin Skinner, Les fondements de la pensée politique moderne, trans. Jérome Grossman and Jean-Yves Pouilloux, Paris, Albin Michel, "Bibliothèque de l'évolution de l'humanité", 2009, p. 768, Nicolas Le Roux, Le Roi, la cour, l'État, De la Renaissance à l'absolutisme, Seyssel, Champ vallon, 2013, p. 107.

30. Innocent Gentillet, Discours sur les moyens de bien gouverner et maintenir en bonne paix un royaume ou autre principauté, [...] Contre Nicolas Machiavel Florentin, s.l., s. éd., 1576, Epistre, Jean Balsamo, “Un livre écrit du doigt de Satan", la découverte de Machiavel et l'invention du machiavélisme en France au XVI ${ }^{\mathrm{e}}$ siècle”, in Le pouvoir des livres à la Renaissance, D. Courcelles ed., Paris, École nationale des Chartes, 1998.

31. It should be remembered that Henri had been baptised Alexandre and François d'Alençon was baptised Hercule. See also Nicolas Le Roux, Le Roi, la cour, l'État, op. cit.

32. "Lors me trouvant entre ces deux extrémités, ou de manquer à la fidélité que je devais à mon frère, et mettre sa vie en danger, ou de jurer contre la vérité, chose que je n'eusse voulue pour éviter mille morts, je me trouvai en si grande perplexité que, si Dieu ne m'eût assisté, ma façon eût assez témoigné, sans parler, ce que je craignais qui fût découvert. [...] je composai tellement mon visage et mes paroles, qu'elle ne put rien connaître que ce que je voulais, et que je n'offensai mon âme ni ma conscience par aucun faux serment." (p. 175)

33. "[ma mère] commanda à mon frère et à moi d'aller changer nos habits [...] Elle y fut obéie pour les choses qui se pouvaient dévêtir ou remettre; mais pour le visage, qui est la vive image de l'âme, la passion du juste mécontentement que nous avions s'y lisait aussi apparente qu'elle avait été imprimée, avec la force et violence du dépit et juste dédain que nous ressentions par l'effet de tous les actes de cette tragi-comédie." (p. 172-173)

34. "[...] le chevalier de Seurre (que la reine ma mère avait baillé à mon frère pour coucher en sa chambre, et qu'elle prenait plaisir d'ouïr quelquefois causer, pour être d'humeur libre, et qui disait de bonne grâce ce qu'il voulait, tenant un peu de l'humeur d'un philosophe cynique) [...] [qui déclare] 'C'est trop peu, [...] pour faire à bon escient, et trop pour se jouer.' Et se tournant vers moi sans qu'elle le pût entendre, me dit: 'Je ne crois pas que ce soit ici le dernier acte de ce jeu ; notre homme (voulant parler de mon frère) me tromperait bien s'il demeurait là'." (p. 173) 
35. Michèle Clément, Le Cynisme à la renaissance, Genève, Droz, 2005, p. 194.

36. Antoine Compagnon, La Seconde main ou le travail de la citation, Paris, Seuil, 1979.

37. “[...] aussi dignes d'être décrites que celles de l'enfance de Thémistocle et d'Alexandre, l'un s'exposant au milieu de la rue devant les pieds des chevaux du charretier qui ne s'était à sa prière voulu arrêter, l'autre méprisant l'honneur du prix de la course, s'il ne le disputait avec des rois." (p. 48)

38. "[...] Peu s'en fallut que je ne lui répondisse, comme Moïse à Dieu en la vision du buisson: 'Que suis-je, moi ?' Envoie celui que tu dois envoyer." (p. 57)

39. “[...] trouvant en moi ce que je ne pensais qui y fût (des puissances excitées par l'objet de ses paroles, qui auparavant m'étaient inconnues bien que [je fusse] née avec assez de courage en moi), revenue de ce premier étonnement, ces paroles me plurent ; et me semblait à l'instant que j'étais transformée, et que j'étais devenue quelque chose de plus que je n'avais été jusqu'alors. Je commençai à prendre confiance de moi-même, et lui dis : 'Mon frère [...]'."

40. "Ce me sera un grand plaisir de vous parler comme à votre frère. Rendez-vous sujette auprès de moi, et ne craignez point de me parler librement, car je le veux ainsi” (p. 58).

41. "La dissimilitude s'ingere d'elle mesme en nos ouvrages [...] La ressemblance ne faict pas tant un comme la difference faict autre", Montaigne, Essais, III, XIII, éd. Villey, p. 1064.

42. "Pour m'estre, dès mon enfance, dressé à mirer ma vie dans celle d'autruy, j'ay acquis une complexion studieuse en cela, et, quand j'y pense, je laisse eschaper au tour de moy peu de choses qui y servent : contenances, humeurs, discours." Ibid., p. 1076.

43. Éliane Viennot, Mémoires, Champion, op . cit., p. 47 : “elle resta l'alliée d'Henri jusqu'aux premiers mois du séjour en Pologne".

44. Thierry Wanegfellen, Catherine de Médicis, Paris, Payot, 2005, p. 369.

45. "[...] il fit une harangue au roi, pour lui rendre raison de tout le maniement de sa charge [...] faite avec tant d'art et d'éloquence, dite avec tant de grâce qu'il se fit admirer de tous les assistants - et d'autant plus que sa grande jeunesse relevait et faisait davantage paraître la prudence de ses paroles (plus convenables à une barbe grise et à un vieux capitaine qu'à une adolescence de seize ans, à laquelle les lauriers de deux batailles gagnées lui ceignaient déjà le front) et que la beauté, qui rend toutes actions agréables florissait tellement en lui qu'il semblait qu'elle fît à l'envi avec sa bonne fortune pour voir laquelle des deux le rendrait plus glorieux." (p. 54-55)

46. "chasseur déloyal", Le Réveille-matin des français et de leurs voisins, composé par Eusebe Philadelphe, Jacques James, Édimbourgh, 1574, n.p. .

47. Mémoires de Mergey, Nouvelle Collection des Mémoires pour servir à l'Histoire de France, ed. Michaud and Poujoulat, Paris, 1838, t. IX, p. 575 : [I responded that it was not sufficient to be aware of it, but that it had to be remedied, and that it was not good enough to run fast, but that one had to set off early; he responded that he had not intention of spending the winter there.] 'je luy repliquay que ce n'estoit pas assez de le cognoistre, mais qu'il y falloit remedier, et que ce n'estoit pas assez de courir fort, mais de partir de bonne heure; lequel me respondit qu'il n'esperoit pas de passer là son hyver'. Mémoires et poésies de Jeanne d'Albret, published by baron de Ruble, Paris, 1893, p. 82. [But it has been about as much use to listen to them as the glasses of an old man of sixty would have been to a twenty year old lady.] "Mais de quoy m'a servi de les escouter, sinon comme à une jeune personne de vingt ans les lunettes d'un vieillard sexagénaire?".

48. Jean Garapon, "Une autobiographie dans les limbes, Les Mémoires de la reine Marguerite”, Marguerite de France Reine de Navarre et son temps, Agen, Centre Mateo Bandello, 1994, p. 205-216, J. Garapon, "Les Mémoires du XVII ${ }^{\mathrm{e}}$ siècle, nébuleuses de genre", Le Genre des Mémoires, essai de définition, Paris, Klincksieck, 1995, p. 259-271, J. Garapon, "Amateurisme littéraire et vérité sur soi, de Marguerite de Valois au cardinal de Retz", vol. 103, RHLF, 2003/2, p. 275-285. É. Viennot, "Conversation, innovation: les Mémoires de Marguerite de Valois et la naissance d'un genre", in 
Marie-Paule De Weerdt-Pilorge (dir.), Mémoires des XVII et XVIII ${ }^{e}$ siècles. Nouvelles tendances de la Recherche, Tours, Cahiers d'histoire culturelle, $\mathrm{n}^{\circ}$ 13, 2003, p. 5-12, http://www.elianeviennot.fr/ Articles/Viennot-MgV-conversation.pdf, p. 4.

49. Anne-Marie Cocula, "Marguerite de Valois, de France et de Navarre: l'impossible identité de la reine Margot", Marguerite de France Reine de Navarre et son temps, Agen, Centre Mateo Bandello, 1994, p. 17-27 and É. Viennot, "Les ambiguïtés identitaires du Je dans les Mémoires de Marguerite de Valois", Le Genre des Mémoires, essai de définition, Paris, Klincksieck, 1995, p. 69-79.

50. Stephen Greenblatt, Renaissance Self-fashioning, from More to Shakespeare, Chicago and London, The University of Chicago Press, 2005, $1^{\text {st }}$ edition 1980.

51. Norbert Elias, La société de cour, op. cit., p. 279.

52. "Platon dict aussi que prudence n'est autre chose que l'execution de cette ordonnance", Montaigne, Les Essais, III, XIII, op. cit., p. 1075.

\section{ABSTRACTS}

The Memoirs are an exercise in self-knowledge that reflects an anthropological outlook. This temporal vision of the human being draws on Marguerite's philosophical knowledge, as well as her conception of history and of politics. As a good humanist, she put the considerable learning she had to the test of lived experience, as well as to that of writing, to a first-hand experience of learning that draws its meaning from the vivacity of an individual's telling. The interaction of these different types of knowledge and their interaction with writing makes her identity.

Les Mémoires sont une entreprise de connaissance de soi-même qui révèlent une anthropologie. Cette vision de l'être dans le temps engage les savoirs philosophiques de Marguerite, sa conception de l'histoire et de la politique. En bonne humaniste, elle met donc les nombreux savoirs qu'elle possède à l'épreuve de l'expérience vécue et de celle de l'écriture, d'une expérience personnelle des savoirs qui prend sens dans la vivacité du discours d'un sujet. L'interaction de ces différents savoirs et leur interaction avec l'écriture fabrique son identité.

\section{INDEX}

Keywords: Marguerite de Valois, The Memoirs, experience, knowledge, authorship

Mots-clés: Marguerite de Valois, Mémoires, expérience, savoir, auctorialité

\section{AUTHORS}

\section{CAROLINE TROTOT}

